\title{
Farklı Bitki Ekstraktlarıyla Kaplamanın Kaşar Peynirlerinin Mikrobiyolojik ve Duyusal Kaliteleri Üzerine Etkileri
}

\author{
Oktay Tomar $^{1 *}$, Gökhan Akarca ${ }^{2}$ \\ ${ }^{1}$ Afyon Kocatepe Üniversitesi, Mühendislik Fakültesi, Gıda Mühendisliği Bölümü, Afyonkarahisar, Türkiye (ORCID: 0000-0001-5761-7157) \\ ${ }^{2}$ Afyon Kocatepe Üniversitesi, Mühendislik Fakültesi, Gıda Mühendisliği Bölümü, Afyonkarahisar, Türkiye (ORCID: 0000-0002-5055-2722)
}

(İlk Geliş Tarihi 26 Aralık 2018 ve Kabul Tarihi 16 Şubat 2019)

(DOI: $10.31590 /$ ejosat.502693)

ATIF/REFERENCE: Tomar, O. \& Akarca, G. (2019). Farklı Bitki Ekstraktlarıyla Kaplamanın Kaşar Peynirlerinin Mikrobiyolojik ve Duyusal Kaliteleri Üzerine Etkileri. Avrupa Bilim ve Teknoloji Dergisi, (15), 86-95.

$\ddot{O} \mathbf{z}$

$\mathrm{Bu}$ çalışmada beş farklı baharatın etanol ekstraktları keçiboynuzu çekirdeğinden elde edilen gamla kaplanmış kaşar peynirleri 28 gün boyunca depolanmış ve bu süre boyunca örneklerin mikrobiyolojik ve duyusal değerlerindeki değişimleri incelenmiştir. Depolama süresi sonunda tüm örneklerin mikroorganizma sayıları artış göstermiştir $(\mathrm{P}<0.05)$. Farklı bitki ekstraktları ilavesi ile kaplanan örneklerin toplam aerobik mezofil bakteri ve psikrofilik bakteri sayılarının, kontrol numunesine kıyasla, ortalama 1 log, maya küf sayılarının ise, ortalama $3.5 \log$ daha düşük olduğu tespit edilmiştir $(\mathrm{P}<0.05)$. Depolama sonunda en düşük toplam aerobik mezofilik bakteri $(4.98 \mathrm{log} \mathrm{kob} / \mathrm{g})$, psikrofilik bakteri (2.81 log kob/g) ve maya küf sayısının (4.59 log kob/g) tarçın ekstraktı içeren gamla kaplanmış kaşar peynir numunelerinde olduğu belirlenmiştir. Ayrica depolama süresi boyunca örneklerimizin hiç birisinde toplam koliform grup ve Staphylococcus aureus türü bakteri gelişimi tespit edilmemiştir. Yapılan duyusal analiz sonuçlarına göre kontrol numunesi hariç tüm örneklerin genel beğeni puanları, ilk 15 gün süresince artış göstermesine karşın, depolama sonunda azalmıştır $(\mathrm{P}<0.05) .28$ günlük depolama süresi sonucunda en fazla beğenilen örnekler 6.80 genel beğeni puanı ile biberiye ekstraktı ile kaplanan peynir numuneleri olmuştur $(\mathrm{P}<0.05)$.

Anahtar Kelimeler: Kaşar, Bitki ekstraktı, Mikrobiyolojik kalite, Biberiye, Tarçın.

\section{The Effects of Coating with Different Plant Extracts on Microbiological and Sensory Attributes of Fresh Kashar Cheese}

\begin{abstract}
In this study, the kashar cheeses coated with the locust bean gum that contained ethanol extracts of five different plants. The changes in microbiological and sensory attributes of the samples were examined during the 28 days storage periods. Microorganism numbers of all samples increased at the end of storage period $(\mathrm{P}<0.05)$. The total number of aerobic mesophilic bacteria and psychrophilic bacteria in the coated with plant extracts samples were found to be $1 \log$ and the number of yeast molds was 3.5 log lower than the control sample (P
\end{abstract}

\footnotetext{
* Sorumlu Yazar: Afyon Kocatepe Üniversitesi, Mühendislik Fakültesi, Gıda Mühendisliği Bölümü, Afyonkarahisar, Türkiye, ORCID: 0000-0001-57617157, oktomar@aku.edu.tr
} 


\section{European Journal of Science and Technology}

$<0.05)$. At the end of storage, it was determined that the lowest total aerobic mesophilic bacteria (4.98 $\log \mathrm{cfu} / \mathrm{g}$ ), psychrophilic bacteria $(2.81 \mathrm{log} \mathrm{cfu} / \mathrm{g}$ ) and yeast mold count (4.59 $\mathrm{log} \mathrm{cfu} / \mathrm{g}$ ) were in the coated cheese samples produced with cinnamon extract. In addition, total coliform group and Staphylococcus aureus bacterial growth were not detected in any of our samples during storage period. According to the results of sensory analysis, the overall acceptability scores of all samples except the control sample increased during the first 15 days but decreased at the end of storage $(\mathrm{P}<0.05)$. As a result of 28 days of storage period, the most admired samples were cheese samples coated with rosemary extract with an overall rating of $6.80(\mathrm{P}<0.05)$.

Keywords: Kashar, Plant extract, Microbiological quality, Rosemary, Cinnamon.

\section{Giriş}

Kaşar; Türkiye'de en çok tüketilen üç peynir çeşidinden birisidir (Çakır \& Çakmakçı, 2018). Benzer peynirler Balkan ülkelerinde de Kaskaval adıyla bol miktarlarda üretilmektedir (Öksüz ve ark, 2001). Peynir, telemesi 1sıtıldığında esnek yapı kazanan ve gerildiğinde uzayan bir yapıya sahip olan ssıl işlem görmüş /pasta filata ailesine mensuptur. Bu özellikleri nedeniyle de Caciocavalle, Provalon, Mozzarella ve Kashkaval ile aynı grupta sınıflandırılır (Çelik ve ark, 2018). Geleneksel üretim prosesi, maya ilavesi ve mayalanma, pıhtı oluşumu, fermantasyon, tuzlu suda (en az $72{ }^{\circ} \mathrm{C}$ derecede) pişirme ve yoğurma, kalıplama ve olgunlaştırma aşamalarından oluşur (Hayaloğlu, 2009).

Türkiye'de kaşar peyniri taze ve olgunlaştırılmış olarak iki farklı şekilde üretilmektedir (Öksüztepe ve ark, 2009). Bu iki kaşar arasındaki en önemli fark süte uygulanan ısıl işlemlerde ve olgunlaştırma sürelerindedir. Olgunlaştırılmış kaşar peyniri, hammadde olarak çiğ sütün kullanılabilmesi, üretiminde geleneksel yöntemlerin (makine yerine insan gücü ile üretim) kullanılması ve en az 120 gün süre ile olgunlaştırıldıktan sonra satışa sunulmasına karşın, taze kaşar peyniri ise; pastörize inek sütünden üretilen ve olgunlaştırılmadan ya da çok kısa (1- 2 gün) bir olgunlaştırma işleminden sonra satışa sunulmasıdır (Anonim, 2015).

Taze olarak tüketilen kaşar peynirlerindeki en büyük problemlerden birisi, peynirin ambalajı açıldıktan çok kısa süre sonra yüzeyde meydana gelen küf gelişmesidir. Taze kaşar peynirinin su aktivitesi küf gelişmesi için ideal sınırlar içerisinde olduğundan ve kaşar üretiminde küf gelişimini engelleyici katkı kullanımının yasak olması nedeniyle üretilen kaşarların büyük bir kısmı küfler tarafından tüketilemez hale getirilmektedir.

20 yüzyılın sonlarından itibaren baharatların gıdalarda kullanım amaçları dışındaki etkileri üzerinde yapılan çalışmalar önem kazanmıştır. Bu amaçla yapılan pek çok araştırma sonucunda baharatların pek çoğunun antibakteriyel, antifungal ve antiviral etkiye sahip oldukları ortaya konulmuştur (Grădinaru ve ark, 2018; Vijayan \& Mazumder, 2018; İbrahim ve ark, 2017; Boyraz \& Ozcan, 2005).

Adaçayı (Salvia officinalis L.) Labiatae / Lamiaceae familyasına ait bitkidir. Bugün bütün Dünya çapında yetişmesine karşın orijini Orta Doğu ve Akdeniz bölgelerine özgüdür (Garcia ve ark, 2016). Adaçayı Esansiyel yağının bileşiminde başlıca; borneol, kafur, karyofilen, sineol, elemen, humulen, leden, pinen ve thujon yer almaktadır (Hayouni ve ark, 2008). Biberiye (Rosmarinus officinalis L.) ise, Laminaceae familyasına aittir. Dünyanın birçok yerinde, bu bitki gıda, içecek ve kozmetik sanayisinde yaygın olarak kullanılmaktadır (Mohamed ve ark, 2016). Bitkinin bilinen farmakolojik etkilerinin, bileşiminde bulunan rosmarinik asit, karnosik asit ve karnosol gibi fenolik bileşenlerden geldiği belirtilmektedir (Mara ve ark, 2014). Aynı Biberiye gibi kekik'de (Tymus vulgaris L.) Laminaceae familyasına ait bir bitkidir. Esansiyel yağının başlıca bileşenleri, Thymol $(\% 48,9)$ ve p-cymene $(\% 19,0)$ den oluşmaktadır (Sokovic ve ark, 2009). Tarçın ise, (Cinnamomum zeylanicum L.) insanlık tarihinin bilinen en eski baharatlarından birisi olup, Lauraceae familyasına aittir. Ana vatanı Güney Asya olan bitkinin majör bileşenleri; sinemaldehit (\%61) ve eugenol (\%30)'dur (Cabello ve ark, 2009; Kahraman ve ark, 2014). Zingiberaceae familyasının bir üyesi olan Zencefil ise; bugün Afrika ve diğer tropik bölgelerde de yetişmesine karşın anavatanı Asya olan bir bitkidir (Singletary, 2010). Zencefil, kalın köklere sahip, dik gövdeli, çok yıllık bir bitkidir. Esansiyel yağında başlıca monoterpenoid ve seskiterpenoidlerden oluşan 50'den fazla bileşen tanımlanmıştır (Arablou \& Aryaeian, 2014).

Bu çalışmada; beş faklı baharatın (Adaçayı, Biberiye, Kekik, Tarçın ve Zencefil) etanol ekstrakları keçiboynuzu çekirdeğinden elde edilen gama ilavesiyle edilen karışımla kaplandıktan sonra depolanan taze kaşar peynirlerinin mikrobiyolojik ve duyusal kalitelerindeki değişiminin incelenmesi amaçlanmıştır.

\section{Materyal ve Metot}

\subsection{Materyal}

Kaşar peynirlerinin üretiminde holstein cinsi ineklerin sütleri (Kuru madde \%12.24, Protein \%3.06, Yağ \% 3,32 ve pH 6.26) kullanılmıştır. Sütler Afyonkarahisar ilinde faaliyet gösteren bir süt üreticisinden sağlanarak, soğuk zincir altında Afyonkarahisar ilinde bulunan bir süt fabrikasına getirilmiştir. Peynirlerin üretimi yine aynı fabrikada Çakmakçı'nın (2011) belirttiği proses aşamaları modiye edilerek (Şekil 1.) gerçekleştirilmiştir.

\subsection{Kaplama Materyali}

Kaşar peynirlerinin kaplanmasında Adaçayı, Kekik, Biberiye, Tarçın ve Zencefil baharatlarının etanol ekstrakları kullanılmıştır. e-ISSN: 2148-2683 


\subsection{Ekstraktların Hazırlanması}

Araştırma da kullanılan baharatlar, Afyonkarahisar ilinde faaliyet gösteren yerel bir marketten temin edildi. Her bir baharat ögütücü değirmen yardımı ile toz haline getirildi. Toz haline getirilen baharatlardan 100'er gram tartılarak, üzerlerine 400 ml \% 80 'lik etil alkol ilave edildi. Ardından 24 saat boyunca shaker (WiseShake® SHO-2D) kullanılarak 120 rpm de karıştırıldı. Süre sonunda karışım sterilize $22 \mathrm{~mm}$ filtre kağıdından süzülerek, rotary evaporatöre (Heidolph Hei-VAP value) alınarak $100 \mathrm{rpm}$ devirde ve $60{ }^{\circ} \mathrm{C}$ sıcaklıkta alkol ve ekstrak kısmı birbirinden ayrıldı. Bu işlem çalışmada kullanacağımız kaşarları kaplamaya yetecek kadar ekstrakt elde edilene kadar devam edildi.

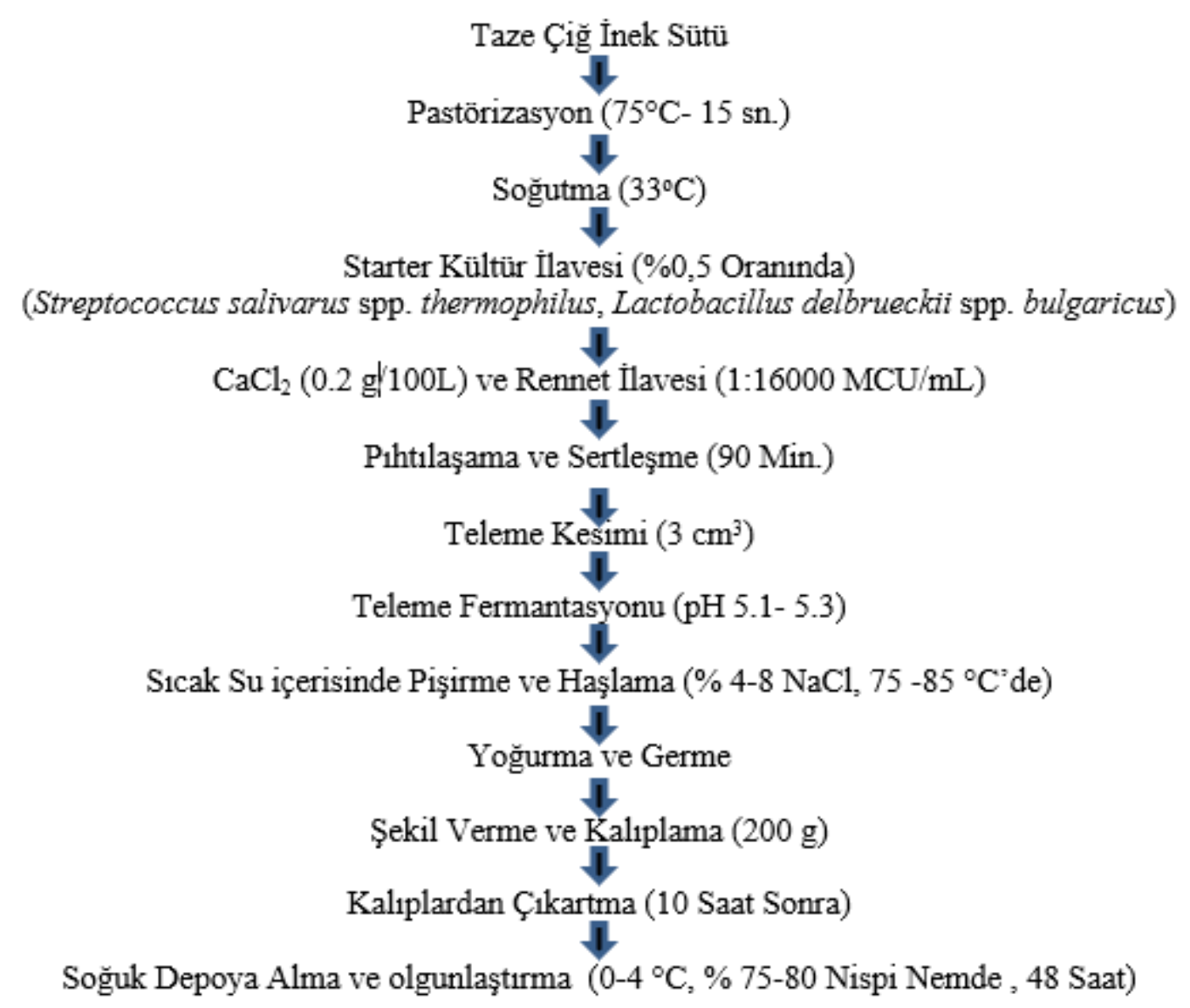

Şekil 1. Kaşar Peynir Üretiminin Akış Diyagramı 


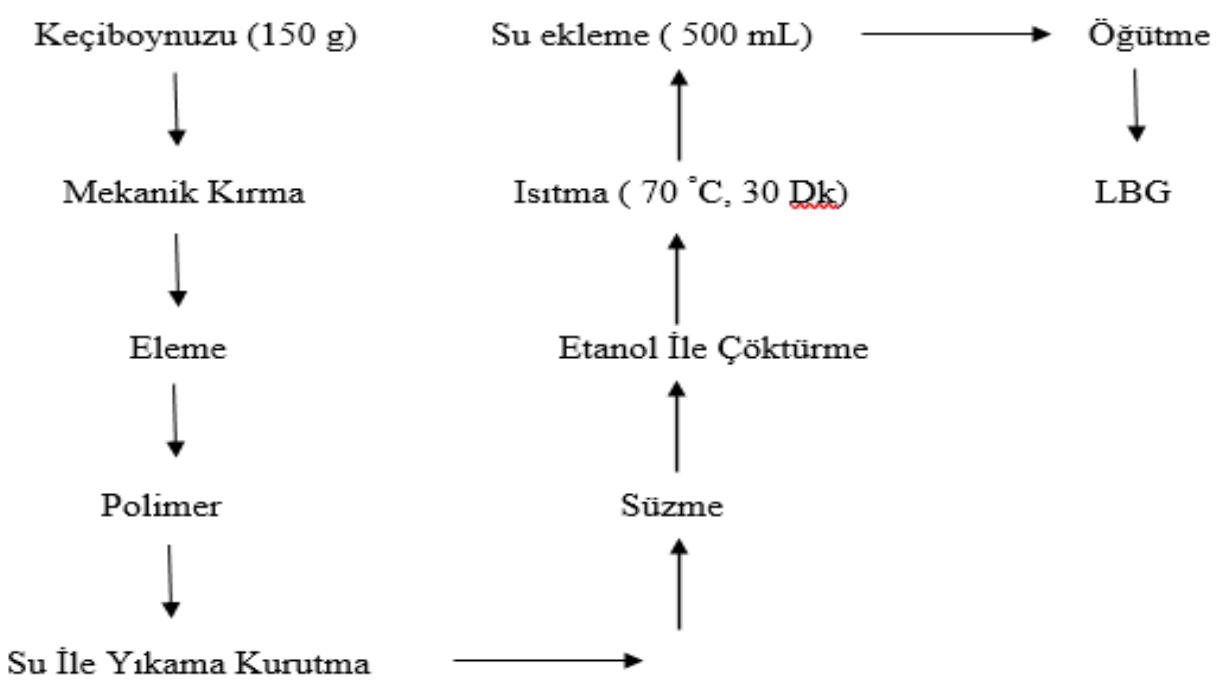

Şekil 2. Locus Bean Gum (LBG) Eldesi

\subsection{Keçiboynuzu Gamının Elde Edilmesi}

Kaplama malzemesi olarak keçiboynuzu çekirdeklerinden elde edilen gam (Locust Bean Gum) (LBG) kullanıldı. LBG Aydınlı ve Tutas (2000)'in belirttiği metot kullanılarak elde edildi (Şekil 2).

\subsection{Polimer Kaplama Malzemesinin Hazırlanması ve Kaşar Peynirlerinin Kaplanması}

Karışımda kullanılacak kaplama malzemesinin hazırlanmasında uygulanacak formül, Durupınar (2015)'in belirttiği metodun modifiye edilmesi ile belirlendi. Bu amaçla $1000 \mathrm{~mL}$ 'lik bir beher içerisine 2,55g LBG tartılarak üzerine $150 \mathrm{~mL}$ saf su ilave edilerek manyetik karıştırıcılı 1 sıııcı yardımı ile $70{ }^{\circ} \mathrm{C}$ ' ye kadar ısıtıldı. Ardından plastikleştirici olarak kullanılan sorbitolden $0,020 \mathrm{~g}$ eklendi. Denemede kullanılacak LBG ve sorbitol miktarları daha önce yapılan ön denemeler sonucunda belirlendi. Karışım 30 dakika süresince karıştırıldıktan sonra homojenizatör yardımıyla $13000 \mathrm{rpm}$ devirde yaklaşık $5 \mathrm{dk}$ süre karıştırılarak homojen hale getirildi. Ardından çözelti içerisinde bulunması muhtemel hava kabarcıklarının uzaklaştırılması maçı ile 60 dakika süre ile orbital karıştırıcıda karıştırıldı. Karışımın içerisinde bulunması muhtemel hava kabarcıklarının uzaklaştırılması sağlandı. İşlem sonunda hazır hale gelen karışım içerisine miktarı elde edilen bitki ekstraklarından ayrı ayrı \%15 oranında ilave edilerek homojenizatör yardımıyla iyice karıştırıldı.

Ardından taze kaşar peynirleri elde edilen bu karışım içerisine daldırılarak $10 \mathrm{dk}$ süre ile bekletildi. Süre sonunda kaşarlar kaplama malzemesi içerisinden çıkartılarak süzüldü ve $4{ }^{\circ} \mathrm{C}$ de, $\%$ 75-85 nispi neme sahip soğuk odalarda aerobik koşullarda 28 gün süre ile depolandi.

\subsection{Mikrobiyolojik Analizler}

Mikrobiyolojik analizler depolamanın 0, 7, 15,21 ve 28. Günlerinde yapıldı. Bu amaçla öncelikle, aseptik koşullarda $10 \mathrm{~g}$ kaşar numunesi alındı. $90 \mathrm{ml}$ steriliz ringer çözeltisi ilave edilerek (1:9 w/v) stomacher'de (Lab-Blender 400, London, UK) 3 dakika süre ile homojenize edildi. Steriliz edilen bu karışımdan $1 \mathrm{ml}$ alınarak içerisinde $9 \mathrm{ml}$ sterile ringer çözeltisi bulunan tüp içerisine ilave edildi ve vortex yardımı ile (IKA MS3, Germany) karıştıııldı. Bu sayede $10^{-2}$ lik dilusyon hazırlandı. İşleme aynı şekilde devam edilerek seri $10^{-6}$ 'ya kadar seri dilusyonlar hazırlandı (Anonim, 2001).

\subsubsection{Toplam Aerobik Mezofilik Bakteri (TAMB) Sayısı}

Dilusyonların her birinden, çift paralel olacak şekilde, steril pipet yardımı ile $0.1 \mathrm{ml}$ alınarak Plate Count Agara (Merck 1.05463) ekim yapıldı ve örneğin steril drigalski spatülü yardımı ile besiyerinin yüzeyine homojen bir şekilde yaılması sağlandı. Örneğin besiyeri tarafından emilmesi beklendikten sonra $\left(15 \mathrm{dk}\right.$.) petri kutuları aerobik koşullarda $37^{\circ} \mathrm{C}$ de $24-48$ saat süre ile inkubasyona bırakıldı. İnkubasyon süresi sonunda oluşan kolnilerden 30-300 arasındaki sayıda olanlar sayılarak toplam aerobik mezofilik bakteri sayısı hesaplandı (ISO, 2013a;b). 


\subsubsection{Psikrofilik Bakteri Sayısı}

Avrupa Bilim ve Teknoloji Dergisi

Hazırlanan her bir dilusyondan, steril pipet yardımı ile çifter paralel olacak şekilde $0.1 \mathrm{ml}$ alınarak Plate Count Agara (Merck 1.05463) ekim yapıldı. Besiyeri tarafından örnek emildikten sonra petri kutuları aerobik koşullarda $4{ }^{\circ} \mathrm{C}$ de $5-7$ gün süre ile inkubasyona bırakıldı. İnkubasyon süresi sonunda oluşan kolnilerden 30-300 arasındaki sayıda olanlar sayılarak toplam maya küf sayısı hesaplandı (FAO,1992).

\subsubsection{Toplam Koliform Grup Bakteri (TKGB) Sayısı}

Kaşar örneklerinden hazırlanan dilusyonlardan 0,1 ml alınarak Violet Bile Agara (VRB) (Merck 1.01406) ekim yapıldı.Ardından steril drigalski spatülü yardımı ile örnek besiyeri yüzeyine homojen bir şekilde yayıldı. Besiyerinin örneği emmesinin ardından, daha önceden hazırlanmış $30-35^{\circ} \mathrm{C}$ 'deki VRB agardan birkez daha $(10 \mathrm{ml})$ petri kutularına döküldü. Besiyerinin katılaşmasının ardından petri kutular $30^{\circ} \mathrm{C}$ de $24-48$ saat süre ile inkubasyona bırakıldı. İnkubasyon süresi sonunda oluşan kolnilerden 30-300 arasındaki sayıda olanlar sayılarak toplam koliform grup bakteri sayısı hesaplandı (ISO, 1991).

\subsubsection{Maya ve Küf Sayısı}

Hazırlanan seri dilusyonların her birinden (çift paralel) $0,1 \mathrm{ml}$ steril pipet yardımı ile alınarak Dichloran Rose Bengal Chloramphenicol Agara (DRBC) (Merck 1.00466) ekim yapıldı. Ardından örnek steril drigalski spatülü yardımı ile besiyerinin yüzeyine homojen bir şekilde yayıldı ve besiyerleri aerobik koşullarda $25{ }^{\circ} \mathrm{C}$ de 5-7 gün süre ile inkubasyona bırakıldı. İnkubasyon süresi sonunda oluşan kolnilerden 30-300 arasındaki sayıda olanlar sayılarak toplam maya küf sayısı hesaplandı (ISO, 2008).

\subsubsection{Staphylococcus aureus Türü Bakteri Sayıst}

Staphylococcus aureus türü bakteri sayısı analizlinde hazırlana tüm dilüsyonlardan çift paralel olacak şekilde 0,1 steril bir pipet ile alınarak Baird Parker Agara (Merck 1.05406) ekim yapıldı. Steril bir drigalski yapdımı ile örnek besiyeri yüzeyine homojen bir şekilde yayıldıktan sonra $15 \mathrm{Dk}$. Süre ile örneğin besiyeri tarafindan emilmesi için beklendi. Ardından petri kutuları $37^{\circ} \mathrm{C}$ de $24-48$ saat süre ile inkubasyona bırakıldı. İnkubasyon süresi sonunda oluşan kolnilerden 30-300 arasındaki sayıda olanlar sayılarak toplam koliform grup bakteri sayısı hesaplandı (ISO, 1999).

\subsection{Duyusal Analizler}

Kaşar peynirlerinin duyusal değerlendirilmesi, depolamanın 0., 15. ve 28.günlerinde olacak şekilde 3 ayrı zaman diliminde gerçekleştirildi. Kaşar numunelerinin duyusal değerlendirilmesi, Akarca ve ark, (2016), belirtilen duyusal test parametreleri modifiye edilerek oluşturulan puan kartları kullanılmış, farklılıklar bir skala üzerinde puanlama sistemi ile belirlenmiştir. Duyusal analizler, Afyon Kocatepe Üniversitesi Gıda Mühendisliği Bölümü'nden yirmi eğitimli panelist tarafindan gerçekleştirildi. Örnekler; görünüş, renk, yapı, tat ve koku ile genel beğeni kriterlerince, hedonik skala ile 1-9 arasında değerlendirildi: 1-3(kabul edilemez), 4-5 (kabul edilebilir), 6-7 (iyi), 8-9 (çok iyi) (Önoğur \& Elmac1,2012; Anonim, 2012).

\section{8. İstatistiksel Analizler}

Deney dizaynı, altı numune (Kontrol, adaçayı, biberiye, kekik, tarçın ve zencefil), 5 depolama zamanı (0., 7., 15., 21., 28. günler) ve iki tekrar olacak şekilde uygulandı. Verilerin istatistiksel analizi, SPSS programını 17.0.1 versiyonunun varyans analizi kullanılarak yapılmıştır (Anonim, 2008). Anlamlı bir değere sahip ortalama değerler, Duncan'ın çoklu rangle testleri ile karşılaştırıldı.

\section{Araştırma Sonuçları ve Tartışma}

\subsection{Toplam Aerobik Mezofilik Bakteri (TAMB) Sayısı}

Depolama başlangıcında en düşük TAMB sayısına 4.08 log kob/g ile kaplama materyaline adaçayı ilave edilen, en yüksek sayıya ise; $4.45 \log \mathrm{kob} / \mathrm{g}$ ile kekik ilavesi ile kaplanan kaşar örneği olduğu belirlenmiştir. Buna karşın depolamanın sonuncu gününde en düşük TAMB sayısına 4.98 log kob/g ile LBG içerisine tarçın ekstraktı ilave edilerek kaplana örnek olduğu, en yüksek sayısnın ise yine kontrol örneği olduğu tespit edilmiştir (Tablo 1.). 
Tablo 1. Kaşar Örneklerinin Depolama Süresinceki Toplam Aerobik Mezofilik Bakteri Sayıları (log kob/g)

\begin{tabular}{lcccccc}
\hline & Kontrol & Adaçayı & Biberiye & Kekik & Tarçın & Zencefil \\
\hline 0.Gün & $4.36^{\mathrm{Ac}}$ & $4.08^{\mathrm{Ad}}$ & $4.11^{\mathrm{Ac}}$ & $4.45^{\mathrm{Ac}}$ & $4.13^{\mathrm{Ad}}$ & $4.27^{\mathrm{Ac}}$ \\
7.Gün & $5.12^{\mathrm{Ab}}$ & $4.82^{\mathrm{ABc}}$ & $4.48^{\mathrm{Bbc}}$ & $4.65^{\mathrm{ABbc}}$ & $4.36^{\mathrm{Bc}}$ & $4.51^{\mathrm{ABbc}}$ \\
15.Gün & $6.19^{\mathrm{Aab}}$ & $5.08^{\mathrm{BCb}}$ & $4.89^{\mathrm{BCb}}$ & $5.16^{\mathrm{Bb}}$ & $4.67^{\mathrm{Cb}}$ & $5.23^{\mathrm{Bc}}$ \\
21.Gün & $6.68^{\mathrm{Aa}}$ & $5.48^{\mathrm{Bab}}$ & $5.33^{\mathrm{BCa}}$ & $5.43^{\mathrm{Bab}}$ & $4.75^{\mathrm{Cb}}$ & $5.68^{\mathrm{ABb}}$ \\
28.Gün & $6.81^{\mathrm{Aa}}$ & $5.77^{\mathrm{Ba}}$ & $5.41^{\mathrm{CBa}}$ & $5.69^{\mathrm{Ba}}$ & $4.98^{\mathrm{Ca}}$ & $6.03^{\mathrm{ABa}}$ \\
\hline
\end{tabular}

A - C $(\rightarrow)$ : Aynı satırdaki farklı harflere sahip değerler istatistiksel olarak önemli ölçüde farklılık göstermektedir $(\mathrm{p}<0.05)$.

$\mathrm{a}-\mathrm{d}(\downarrow)$ : Aynı sütunda farklı harflere sahip değerler istatistiksel olarak önemli ölçüde farklılık göstermektedir $(\mathrm{p}<0.05)$.

Kaplama materyal içerisine farklı baharatların ilavesinin kaşar örneklerinde TAMB sayısının artışını engellediği, özellikle tarçın ve biberiyenin bu artışı en fazla engelleyen baharatlar olduğu belirlenmiştir.

\subsection{Psikrofilik Bakteri Sayısı}

Farklı baharat etanol ekstraklarının LGB içerisine ilavesi ile edilen kaplama malzemesi ile kaplana kaşar peyniri örneklerinin 28 günlük depolama süresi boyunca psikrofilik bakterilerinin sayıları Tablo 2'de gösterilmiştir.

Depolama süresi boyunca tüm örneklerin psikrofilik bakteri sayıları artış göstermesine karşın en az artışın tarçın ekstratı ilave edilerek depolanan kaşar peyniri örneklerinde olduğu belirlenmiştir. Depolama süresi sonunda en fazla psikrofilik bakteri sayısı 3.93 log kob/g ile kontrol örneğinde, en düşük psikrofilik bakateri sayısı ise 2.81 log kob/g ile tarçın ilavesi ile kaplana kaşar peyniri örneklerinde olduğu tespit edilmiştir.

Wang ve ark, (2018) tarçın esansiyel yağlarının Porphyromonas gingivalis üzerinde antibakteriyel etkiye sahip olduğunu ve bu etkinin tarçın esansiyel yağının bileşiminde başlıca bulunan sinemaldehit'den kaynaklandığını bildirmişlerdir. Benzer şekilde Ünlü ve ark, (2010) tarçın esansiyel yağının 21 farklı bakteri üzerindeki antimikrobiyal etkisini araştırdıkları çalışmalarında tarçının araştırmada kullanılan tüm bakyeriler üzerinde kuvvetli bir antibakteriyel etki gösterdiğini b tespit ettkilerini bildirmişlerdir.Araştırmacılar antibakteriyel etkinin tarçının ana bileşen olan sinemldehitten kaynaklandığını ifade etmişlerdir.

Tablo 2. Kaşar Örneklerin Depolama Süresinceki Psikrofilik Bakteri Saylları (log kob/g)

\begin{tabular}{|c|c|c|c|c|c|c|}
\hline & Kontrol & Adaçayı & Biberiye & Kekik & Tarçın & Zencefi \\
\hline o.Gün & $2.08^{\mathrm{Ad}}$ & $<2^{\mathrm{Ad}}$ & $<2^{\mathrm{Bc}}$ & $<2^{\mathrm{Ac}}$ & $<2^{\mathrm{ABc}}$ & $<2^{\mathrm{Ac}}$ \\
\hline 7.Gün & $2.84^{\mathrm{Ac}}$ & $2.16^{\mathrm{Bc}}$ & $<2^{\mathrm{ABc}}$ & $2.24^{\mathrm{Bb}}$ & $<2^{\mathrm{Cc}}$ & $2.44^{\mathrm{ABbc}}$ \\
\hline 15.Gün & $3.36^{\mathrm{Ab}}$ & $2.48^{\mathrm{Cb}}$ & $2.53^{\mathrm{BCb}}$ & $2.71^{\mathrm{Bb}}$ & $2.12^{\mathrm{Db}}$ & $2.62^{\mathrm{Bb}}$ \\
\hline 21.Gün & $3.71^{\mathrm{Aab}}$ & $2.79^{\mathrm{Bab}}$ & $2.87^{\mathrm{Bab}}$ & $3.04 \mathrm{~A}^{\mathrm{Bab}}$ & $2.58^{\mathrm{Cab}}$ & $2.99^{\mathrm{Bb}}$ \\
\hline 28.Gün & $3.93^{\mathrm{Aa}}$ & $3.13^{\mathrm{Ba}}$ & $3.04^{\mathrm{Ba}}$ & $3.36^{\mathrm{ABa}}$ & $2.81^{\mathrm{Ca}}$ & $3.41^{\mathrm{ABa}}$ \\
\hline
\end{tabular}

A - C $(\rightarrow)$ : Aynı satırdaki farklı harflere sahip değerler istatistiksel olarak önemli ölçüde farklılık göstermektedir (p<0.05).

$\mathrm{a}-\mathrm{d}(\downarrow)$ : Aynı sütunda farklı harflere sahip değerler istatistiksel olarak önemli ölçüde farklılık göstermektedir $(\mathrm{p}<0.05)$.

\subsection{Maya ve Küf Sayısı}

Farklı bitki ekstrakları ilave edilerek kaplanan ve 28 gün süre ile depolanan kaşar örneklerine ait maya küf sayıları Tablo 3'de gösterilmiştir. 


\begin{tabular}{lcccccc}
\hline & Kontrol & Adaçayı & Biberiye & Kekik & Tarçın & Zencefil \\
\hline 0.Gün & $3.31^{\mathrm{Ad}}$ & $3.42^{\mathrm{Ad}}$ & $3.36^{\mathrm{Ad}}$ & $3.58^{\mathrm{Ae}}$ & $3.28^{\mathrm{Ac}}$ & $3.54^{\mathrm{Ad}}$ \\
7.Gün & $4.46^{\mathrm{Ac}}$ & $3.68^{\mathrm{CBc}}$ & $3.85^{\mathrm{Bcd}}$ & $4.28^{\mathrm{ABd}}$ & $3.55^{\mathrm{Cbc}}$ & $4.32^{\mathrm{ABcd}}$ \\
15.Gün & $5.52^{\mathrm{Abc}}$ & $4.12^{\mathrm{CDb}}$ & $4.46^{\mathrm{Cc}}$ & $5.14^{\mathrm{ABc}}$ & $3.88^{\mathrm{Db}}$ & $4.96^{\mathrm{Bc}}$ \\
21.Gün & $7.31^{\mathrm{Ab}}$ & $4.65^{\mathrm{Bab}}$ & $5.73^{\mathrm{Cb}}$ & $6.68^{\mathrm{ABb}}$ & $4.02^{\mathrm{BCab}}$ & $6.07^{\mathrm{Bb}}$ \\
28.Gün & $9.86^{\mathrm{Aa}}$ & $5.45^{\mathrm{Ca}}$ & $6.62^{\mathrm{CBa}}$ & $7.72^{\mathrm{Ba}}$ & $4.59^{\mathrm{Da}}$ & $7.22^{\mathrm{Ba}}$ \\
\hline
\end{tabular}

A - D $(\rightarrow)$ : Aynı satırdaki farklı harflere sahip değerler istatistiksel olarak önemli ölçüde farklılık göstermektedir (p<0.05).

$\mathrm{a}-\mathrm{e}(\downarrow)$ : Aynı sütunda farklı harflere sahip değerler istatistiksel olarak önemli ölçüde farklılık göstermektedir $(\mathrm{p}<0.05)$.

Depolama başlangıcında örneklerin maya küf sayılarının birbirlerine yakın olduğu (3.42 log kob/g) belirlenmiştir. Depola manın 7. gününden itibaren örneklerin maya küf sayılarında artış olduğu ve depolama süresince bu artışın devam ettiği tespit edilmiştir $(\mathrm{P}<0.05)$. Bitki ekstrakları ile kaplanan tüm örneklerin maya küf sayıların depolama süresi boyunca kontrol örneğine kıyasla daha düşük olduğu yapılan analizler sonucunda ortaya konulmuştur. Depolamanın 28. gününde en fazla maya küf sayısına sahip örneğin $9.86 \mathrm{log} \mathrm{kob} / \mathrm{g}$ $(\mathrm{P}<0.05)$ ile kontrol örneği, en düşük maya küf sayısına ise; $4.59 \log \mathrm{kob} / \mathrm{g}(\mathrm{P}<0.05)$ ile tarçın ekstraktı ile kaplanan kaşar örneği olduğu bunu $5.45 \mathrm{log} \mathrm{kob} / \mathrm{g}$ ile adaçayı ekstraktı ile kaplanan kaşar numunesinin izlediği tespit edilmiştir. Rajkovic ve ark. (2015) yaptıkları araştırmada tarçın esansiyel yağlarının Aspergillus flavus üzerinde antifungal etki gösterdiklerini bildirmişlerdir. Benzer şekilde Cömöri ve ark, (2013) çalışmalarında da Tarçın ve Adaçayı esansiyel yağlarının Aspergillus parasiticus var.globosus, Fusarium graminearum ve Fusarium culmorum türü küfler üzerinde antifungal etkisi olduğunu bildirmişlerdir.

Örneklerimizin hiç birisinde depolama süresi boyunca toplam koliform grubu ve Staphylococcus aureus türü bakteri gelişimi gözlenmemiştir.

\subsection{Duyusal Değerlendirme}

Beş farklı baharat ekstraktı ile kaplanarak depolanan kaşar örneklerinin duyusal analiz sonuçları Tablo 4'de gösterilmiştir. Depolamanın başlangıcında kontrol numunesi 7.75 ile en yüksek görünüş puanına sahip olan örnek olmasına karşın örneğin derecelendirmesi depolama süresi boyunca azalarak 28. Günde 5.50'ye düşmüştür $(\mathrm{P}<0.05)$. Kontrol örneğinin ardından en yüksek ikinci görünüş puanı 6.90 ile adaçayı ekstraktı ile kaplanan kaşar numunesine ait olup, bu örneği 6.85 ile biberiye ve 6.80 ile kekik ekstrakları ile kaplanan örnekler izlemiştir. Her üç örneğinde görünüş puanları depolama süresince azalmasına karşın kontrol örneğine kıyasla daha yüksek olduğu tespit edilmiştir. $(\mathrm{P}<0.05)$.

Kontrol örneğinin renk puanlarının diğer örneklere kıyasla, depolamanın başlangıcında daha yüksek olduğu (7.90) belirlenmiştir. Depolama süresi boyunca renk değerleri de görünüş değerlerine benzer şekilde azalma göstermiştir $(\mathrm{P}<0.05)$. Depolama başlangıcında en düşük renk puanına 6.05 ile tarçın ekstraktı ile kaplanan örneğin sahip olduğu tespit edilmiştir. Kontrol numunesi hariç beş farklı ekstrakt ile kaplanan örneklerin renk puanları, depolamanın 15. gününde artış göstermesine karşın $(\mathrm{P}<0.05)$ depolamanın son gününde azalmıştır. Buna karşın kontrol numunesine kıyasla hepsinin puanı daha yüksektir $(\mathrm{P}<0.05)$.

Yapı puanları depolamanın başlangıcında tüm numunelerde birbirine yakın değerlerde tespit edilmiş olup ( $\mathrm{P}>0.05)$ tüm numunelre depolamanın ilk 15 günü artış göstermesine karşın sonraki günlerde düşüş göstermiştir $(\mathrm{P}<0.05)$. 28. Depolama gününde en düşük yap1 puanı 5.85 ile kontrol numunesine aitken, en yüksek yapı puanının 6.55 ile biberiye ekstraktı ile kaplanan örnekler olduğu yapılan değerlendirmeler sonucu ortaya konulmuştur.

Kaşar örneklerinin tat ve koku puanları kontrol numunesi hariç depolamanın ilk 15 günü artış göstermesine karşın son gününde azalmıştır $(\mathrm{P}<0.05)$. Depolama sonunda en yüksek tat ve koku puanına sahip örneğin; 6.80 ile biberiye ekstraktı kaplı kaşar numunesi olduğu belirlenmiştir. Buna karşın kontrol numunesinin tat ve koku puanları ise; depolama süresinde azalış göstermiştir $\quad(\mathrm{P}<0.05)$. Depolamanın 28. gününde bu numunenin tat ve koku puanı 5.80 olarak tespit edilmiştir.

Genel beğeni puanları (kontrol numunesi hariç) depolama süresinin ilk 15 günü boyunca az da olsa artış göstermesine karşın, depolama süresi sonucunda düşüş göstermiştir $(\mathrm{P}<0.05)$. Genel değerlendirme puanlarına göre, 28 günlük depolama süresince en fazla beğenilen numunenin biberiye ekstraktı ile kaplanan kaşar numunesi olduğu, bunu adaçayı ekstraktı ile kaplanan kaşar numunesinin izlediği belirlenmiştir $(\mathrm{P}<0.05)$. 
Tablo 4. Kaşar Örneklerinin Duyusal Analiz Sonuçları

\begin{tabular}{|c|c|c|c|c|}
\hline \multirow{7}{*}{ Görünüş } & Örnek & 0.Gün & 15.Gün & 28.Gün \\
\hline & Kontrol & $7.75^{\mathrm{aA}}$ & $6.75^{\mathrm{aB}}$ & $5.50^{\mathrm{bcC}}$ \\
\hline & Adaçayı & $6.90^{\mathrm{bA}}$ & $6.80^{\mathrm{aA}}$ & $6.70^{\mathrm{Aa}}$ \\
\hline & Biberiye & $6.85^{\mathrm{bA}}$ & $6.55^{\mathrm{bA}}$ & $6.50^{\mathrm{abA}}$ \\
\hline & Kekik & $6.80^{\mathrm{bA}}$ & $6.35^{\mathrm{bcAB}}$ & $6.05^{\mathrm{bB}}$ \\
\hline & Tarçın & $6.05^{\mathrm{cA}}$ & $5,60^{\mathrm{cB}}$ & $5.55^{\mathrm{bcB}}$ \\
\hline & Zencefil & $6.00^{\mathrm{cA}}$ & $5.75^{\mathrm{cAB}}$ & $5.40^{\mathrm{cB}}$ \\
\hline \multirow{6}{*}{ Renk } & Kontrol & $7.90^{\mathrm{aA}}$ & $7.15^{\mathrm{bB}}$ & $6.05^{\mathrm{cC}}$ \\
\hline & Adaçayı & $7.25^{\mathrm{bAB}}$ & $7.40^{\mathrm{aA}}$ & $7.10^{\mathrm{abB}}$ \\
\hline & Biberiye & $7.35^{\mathrm{bB}}$ & $7.55^{\mathrm{aA}}$ & $7.25^{\mathrm{aB}}$ \\
\hline & Kekik & $7.30^{\mathrm{bAB}}$ & $7.45^{\mathrm{aA}}$ & $7.10^{\mathrm{abB}}$ \\
\hline & Tarçın & $6.60^{\mathrm{cAB}}$ & $6.80^{\mathrm{cA}}$ & $6.40^{\mathrm{bB}}$ \\
\hline & Zencefil & $7.25^{\mathrm{bB}}$ & $7.65^{\mathrm{aA}}$ & $7.35^{\mathrm{aB}}$ \\
\hline \multirow{6}{*}{ Yapı } & Kontrol & $7.65^{\mathrm{aA}}$ & $7.75^{\mathrm{aA}}$ & $5.85^{\mathrm{bB}}$ \\
\hline & Adaçayı & $7.70^{\mathrm{aA}}$ & $7.75^{\mathrm{aA}}$ & $6.40^{\mathrm{aB}}$ \\
\hline & Biberiye & $7.75^{\mathrm{aA}}$ & $7.95^{\mathrm{aA}}$ & $6.55^{\mathrm{aB}}$ \\
\hline & Kekik & $7.50^{\mathrm{aA}}$ & $7.90^{\mathrm{aA}}$ & $6.45^{\mathrm{aB}}$ \\
\hline & Tarçın & $7.65^{\mathrm{aA}}$ & $7.75^{\mathrm{aA}}$ & $6.30^{\mathrm{abB}}$ \\
\hline & Zencefil & $7.70^{\mathrm{aA}}$ & $7.85^{\mathrm{aA}}$ & $6.40^{\mathrm{bB}}$ \\
\hline \multirow{6}{*}{ Tat ve Koku } & Kontrol & $7.75^{\mathrm{aB}}$ & $7.00^{\mathrm{bBC}}$ & $6.55^{\mathrm{cC}}$ \\
\hline & Adaçayı & $7.65^{\mathrm{bB}}$ & $7.85^{\mathrm{aB}}$ & $7.55^{\mathrm{bB}}$ \\
\hline & Biberiye & $8.15^{\mathrm{abA}}$ & $8.40^{\mathrm{aA}}$ & $7.80^{\mathrm{bA}}$ \\
\hline & Kekik & $7.85^{\mathrm{ab}}$ & $8.05^{\mathrm{aA}}$ & $7.40^{\mathrm{bB}}$ \\
\hline & Tarçın & $7.75^{\mathrm{aB}}$ & $7.60^{\mathrm{aB}}$ & $6.55^{\mathrm{bC}}$ \\
\hline & Zencefil & $6.65^{\mathrm{aC}}$ & $6.80^{\mathrm{aC}}$ & $6.05^{\mathrm{bD}}$ \\
\hline \multirow{6}{*}{ Genel Beğeni } & Kontrol & $7.75^{\mathrm{aA}}$ & $7.20^{\mathrm{bAB}}$ & $5.80^{\mathrm{cC}}$ \\
\hline & Adaçayı & $7.30^{\mathrm{aAB}}$ & $7.30^{\mathrm{aA}}$ & $6.75^{\mathrm{bA}}$ \\
\hline & Biberiye & $7.30^{\mathrm{aAB}}$ & $7.35^{\mathrm{aA}}$ & $6.80^{\mathrm{bA}}$ \\
\hline & Kekik & $7.20^{\mathrm{aAB}}$ & $7.25^{\mathrm{aAB}}$ & $6.55^{\mathrm{bAB}}$ \\
\hline & Tarçın & $6.75^{\mathrm{aC}}$ & $6.75^{\mathrm{aC}}$ & $6.10^{\mathrm{bB}}$ \\
\hline & Zencefil & $7.00^{\mathrm{aB}}$ & $7.10^{\mathrm{aB}}$ & $6.40^{\mathrm{bAB}}$ \\
\hline
\end{tabular}

A - D $(\rightarrow)$ : Aynı satırdaki farklı harflere sahip değerler istatistiksel olarak önemli ölçüde farklılık göstermektedir ( $<0.05)$.

$\mathrm{a}-\mathrm{c}(\downarrow)$ : Aynı sütunda farklı harflere sahip değerler istatistiksel olarak önemli ölçüde farklılık göstermektedir ( $<<0.05)$.

Beş farklı baharat estraktının LBG içerisine ilavesiyle elde edilen karışım ile kaplanarak depolanan kaşar numunelerinin tamamının toplam aerobik mezofilik, psikrofilik bakteri ve maya/küf sayıları kontrol numunesine kıyasla daha yüksek çıkmıştır. Tarçın ekstratı ile kaplanan örnekler duyusal değerlendirme sonucunda çok fazla beğenilmemesine karşın en düşük mikroorganizma sayısına sahip örnekler olmuştur.

Tarçının gösterdiği bu kuvvetli antimikrobiyal aktivitenin nedeninin bileşiminde bulunan sinemaldehitten kaynaklandığı belirtilmesine karşın (Ownagh ve ark., 2010) bileşiminde, terpenoidler, esterler, aldehitler, ketonlar, asitler ve alkoller dahil olmak üzere birçok farklı uçucu bileşikten oluştuğu için, antibakteriyel ve antifungal aktiviteyi tek bir bileşik veya bileşik sinıflarıyla ilişkilendirmek oldukça zor olduğu (Ramos ve ark, 2013) bundan dolayı birçok bileşiğin sinerjik etkisinden kaynaklandığı düşünülmektedir.

\section{Sonuç}

Taze kaşar peyniri içerdiği yüksek su aktivitesi değeri (Ortalama: 0.980) nedeniyle ambalajı açıldıktan sonra çok kısa bir raf ömrüne sahiptir. Özellikle küflenme, bu tür peynirlerde en sık rastlanılan problemdir. Bunu önlemek için üretici firmalar potasyum sorbat gibi kimyasal ve natamisin gibi mikrobiyal kaynaklı antifungalları peynire ilave etmekte ya da bu maddelerden oluşan çözeltiler ile kaplamaktadır. Bu katkıların bir kısmının kullanımı yasak olmasına karşın, bir kısmı da ciddi sağlık endişeleri taşımaktadır.

$\mathrm{Bu}$ tür katkı maddelerinin kullanımı yerine, taze kaşar peynirinde en önemli sorun olan küflenmenin engellenmesi adına, bitkisel ekstraklar kullanılabileceği bu çalışma ile ortaya konulmuştur. Konu ile ilgili yapılacak yeni ve detaylı çalışmalar ile, başta süt ürünleri olmak üzere pek çok gıda teknolojisi alanında kullanılan kimyasal ve mikrobiyolojik katkıların yerine daha sağlıklı bitkisel kaynaklı katkıların kullanımına sağlanacağı düşünülmektedir. 


\section{Kaynakça}

\section{Avrupa Bilim ve Teknoloji Dergisi}

Akarca, G., Çağlar, A., \& Tomar, O. (2016). The effects spicing on quality of mozzarella cheese. Mljekarstvo, 66(2), 112-121. http://doi.org/10.15567/mljekarstvo.2016.0203

Anonim. (2001). Turkish Standards Institute. TS 6235 EN ISO 6887-1 Microbiology of food and animal feed general rules of the initial suspension and decimal dilutions of test samples preparation.

Anonim. (2008). SPSS 17.00 for Windows SPSS Inc. Chicago IL, USA.

Anonim. (2012). Gıda Teknolojisi. Duyusal Kontrolleri Yapma. T.C. Millî Eğitim Bakanlığı. Ankara, Turkey

Anonim. (2015). Turkish food codex, Vol. 2015/6. Republic of Turkey ministry of agriculture and forestry Ankara, Turkey.

Arablou, T. \& Aryaeian, N. (2014). The effect of ginger on glycemia and lipid profile. Razi J. Med. Sci, 21(125), 94-103.

Aydinli, M. \& Tutas, M. (2000). Water sorptionand water vapour permeability properties of polysaccharide (Locust Bean Gum) based edible films. LWT-Food Science and Technology, 33(1), 63-67.

Boyraz, N. \& Özcan, M. (2005). Antifungal effect of some spice hydrosols. Fitoterapia, 76(7-8), 661-665.

Cabello, C. M., Bair III, W. B., Lamore, S. D., Ley, S., Bause, A. S., Azimian, S., ve ark. (2009). The cinnamon-derived Michael acceptor cinnamic aldehyde impairs melanoma cell proliferation, invasiveness, and tumor growth. Free Radic. Biol. Med, 15(46), $220-231$.

Celik, O. F., Kurt, S., Tufenk, B., \& Tarakci, Z. (2018). Efficacy of starter culture application using immersion technique on the characteristics of cooked-curd cheeses: Kashar cheese sample. LWT-Food Sci Technol, 96, 222-227. https://doi.org/10.1016/j.1wt.2018.05.031

Cömöri, C., Nacsa-Farkas, E., Kerekes, E.B., Kocsubé, S., Vágvölgyi, C. \& Krisch, J. (2013). Evaluation of five essential oils for the control of foodspoilage and mycotoxin producing fungi. Acta Biologica Szegediensis, 57(2), 113-116.

Çakır, Y. \& Çakmakçı, S. (2018). Some microbiological, physicochemical and ripening properties of Erzincan Tulum cheese produced with added black cumin (Nigella sativa L.), J Food Sci Technol, 55(4), 1435-1443. https://doi.org/10.1007/s13197-018-3058-5

Çakmakçı, S. (2011). Türkiye peynirleri. Ali Adnan Hayaloğlu \& Barbaros Özer (Eds.), Peynir Biliminin Temelleri (s.585-614). İzmir: Sidas Medya Ltd. Şti.

Durupınar, Ü. (2015). Keçiboynuzu çekirdeği bazlı kaplamaların lokumun raf ömrünü uzatmada uygulanması. (Yayınlanmamış yüksek lisans tezi). Afyon Kocatepe Üniversitesi, Fen Bilimleri Enstitüsü, Afyon-Türkiye.

FAO. (1992). Manual of food quality control. "Microbiological Analysis". Food and Agricultural Organization of the United Nations Rome, 1992; 4. Rev. 1, 43-56.

Garcia, C. S. C., Menti, C., Lambert, A. P. F., Moura, S., Calloni, C., Branco, C.S., ve ark. (2016). Pharmacological perspectives from Brazilian Salvia officinalis (Lamiaceae): antioxidant, and antitumor in mammalian cells. An Acad Bras Ci^enc, 88,281-292. http://doi.org/10.3390/antiox5040038

Grădinaru, A. C., Trifan, A., Şpac, A., Brebu, M., Miron, A., \& Aprotosoaie, A. C. (2018). Antibacterial activity of traditional spices against lower respiratory tract pathogens: combinatorial effects of Trachyspermum ammi essential oil with conventional antibiotics. Letters in applied microbiology, 67(5), 449-457. http://doi.org/10.1111/lam.13069.

Hayaloglu, A. A. (2009). Volatile composition and proteolysis in traditionally produced mature Kashar cheese. International Journal of Food Science and Technology, 44(7), 1388-1394.

Hayouni, E. A., Chraief, I., Abedrabba, M., Bouix, M., Leveau, J., Mohammed, ve ark. (2008). Tunisian Salvia officinalis L. and Schinusmolle L. essential oils: their chemical compositions and their preservative effects against Salmonella inoculated in minced beef meat. Int J Food Microbiol, 125, 242-251. http://doi.org/10.1016/j.ijfoodmicro.2008.04.005

Ibrahim, F., Asghar, M. A., Iqbal, J., Ahmed, A. \& Khan, A. B. (2017). Inhibitory effects of natural spices extracts on Aspergillus growth and aflatoxin synthesis. Australian Journal of Crop Science, 11(12),1553-1558. http://doi.org/ 10.21475/ajcs.17.11.12.pne709

ISO. (1991). International Standard Organization. 4832 General Guidance fort the Enumeration of Coliforms Colony Count Technique. Geneva, Switzerland.

ISO. (1999). International Standard Organization. 6888-1 Horizontal Method for the Enumeration of Coagulase- positive Staphylococci Technique using Baird Parker Agar Medium. Geneva, Switzerland. 


\section{European Journal of Science and Technology}

ISO. (2013a). International Standard Organization. 4833-2:2013 Horizontal method for the enumeration of microorganisms -- Part 2: Colony count at 30 degrees $C$ by the surface plating technique. Geneva, Switzerland.

ISO. (2013b). International Standard Organization. 4833-1:2013 Microbiology of the food chain -- Horizontal method for the enumeration of microorganisms -- Part 1: Colony count at 30 degrees $\mathrm{C}$ by the pour plate technique. Geneva, Switzerland.

ISO. (2008). 21527-1:2008 Microbiology of food and animal feeding stuffs -- Horizontal method for the enumeration of yeasts and moulds. Part 1: Colony count technique in products with water activity greater than 0,95 .

Kahraman, A., Akarca, G., \& Tomar, O. (2014). Change of the shelf life of pasteurized milk which added in various amounts of cinnamon. AKU J. Sci. Eng, 15, 1-9.

Mara, A., Oliveira, D., \& Machado, I. D. (2014). Aqueous extract of Rosmarinus officinalis L. Inhibits neutrophil influx and cytokine secretion. Phyther Res. August, (133), 125-133.

Mohamed, W. A. M., Abd-Elhakim, Y. M., \& Farouk, S. M. (2016). Protective effects of ethanolic extract of rosemary against leadinduced hepato-renal damage in rabbits. Exp Toxicol Pathol, 68(8), 451- 461. https://doi.org/10.1016/j.etp.2016.07.003

Ownagh, A., Hasani, A., Mardani, K., \& Ebrahimzadeh, S. (2010). Antifungal effects of thyme, agastache and satureja essential oils on Aspergillus fumigatus, Aspergillus flavus and Fusarium solani. Veterinary Research Forum, 1, 99-105.

Öksüz, Ö., Kurultay, S., \& Simsek, O. (2001). The effect of Brevibacterium linens on some physico-chemical properties and colour intensity of Kashar cheese. Milchwissenschaft, 56(2), 82-85.

Öksüztepe, G., Patır, B., Dikici, A., \& İlhak, O. İ. (2009). Elazığ'da tüketime sunulan vakum paketli taze kaşar peynirlerinin mikrobiyolojik ve kimyasal kalitesi. Firat Üniversitesi Sağllk Bilimleri Veteriner Dergisi, 23(2), 89-94.

Önoğur, A. T., \& Elmac1, Y. (2012). Gldalarda Duyusal Değerlendirme. İzmir: Sidaş Yayıncılık.

Rajkovic, K., Pekmezovic, M., Barac, A., Nikodinovic-Runic, J., \& Arsenijevi, V.A (2015). Inhibitory effect of thyme and cinnamon essential oils on Aspergillus flavus: Optimization and activity prediction model development. Industrial Crops and Products, 65, 713. http://doi.org/ 10.1016/j.indcrop.2014.11.039

Ramos, M., Beltran, A., Valdes, A., Peltzer, M., Jimenez, A., Garrigos, M. ve ark. (2013). Active packaging for fresh food based on the release of carvacrol and thymol. Chemistry \& Chemical Technology, 7, 295-303.http://doi.org/ DOI: 10.1201/b16302-2

Singletary, K. (2010). Ginger an overview of health benefits. Nutr. Today, 45 (4), 171-183.

Soković, M. D., Vukojević, J., Marin, P. D., Brkić, D. D., Vajs, V., \& van Griensven, L. J. L. D. (2009). Chemical composition of essential oils of Thymus and Mentha species and their antifungal activities. Molecules, 14, 238-249.

Unlu, M., Ergene, E., Vardar Unlu G., Sivas Zeytinoglu, H., \& Vural, N. (2010). Composition, antimicrobial activity and in vitro cytotoxicity of essential oil from Cinnamomum zeylanicum Blume (Lauraceae). Food and Chemical Toxicology, 48, 3274-3280.

Vijayan, V., \& Mazumder, A. (2018). In vitro inhibition of food borne mutagens induced mutagenicity by cinnamon (Cinnamomum cassia) bark extract. Drug and chemical toxicology, 41(4), 385-393.http:// doi.org/10.1080/01480545.2018.1439056

Wang, Y., Zhang, Y., Shi, Y., Pan, X., Lu, Y., \& Ca, P. (2018). Antibacterial effects of cinnamon (Cinnamomum zeylanicum) bark essential oil on Porphyromonas gingivalis. Microbial Pathogenesis, 116, 26-32. 